\title{
Self-care and risk reduction habits in older injection drug users with chronic wounds: a cross-sectional study
}

\author{
Maria Elisa Smith', Natanya Robinowitz ${ }^{2}$ Patrick Chaulk ${ }^{2}$ and Kristine E Johnson ${ }^{1 *}$
}

\begin{abstract}
Background: We surveyed a population of injection drug users (IDUs) frequenting the mobile Baltimore City Needle Exchange Program (BNEP) to investigate self-care factors associated with chronic wounds, a significant cause of morbidity especially among older IDUs.

Methods: Participants $\geq 18$ years old completed a survey regarding chronic wounds (duration $\geq 8$ weeks), injection and hygiene practices. Study staff visually verified the presence of wounds. Participants were categorized into four groups by age and wound status. Factors associated with the presence of chronic wounds in participants $\geq 45$ years were analyzed using logistic regression.

Results: Of the 152 participants, $19.7 \%$ had a chronic wound. Of those with chronic wounds, 18 were $\geq 45$ years old (60.0\%). Individuals $\geq 45$ years old with chronic wounds were more likely to be enrolled in a drug treatment program (Odds ratio (OR) 3.4, 95\% Confidence interval (CI) 1.0-10.8) and less likely to use cigarette filters when drawing up prepared drug (OR $0.2,95 \% \mathrm{Cl} 0.03-0.7)$ compared to the same age group without chronic wounds. Compared to individuals $<45$ years old without chronic wounds, individuals $\geq 45$ with a chronic wound were more likely to report cleaning reused needles with bleach (OR 10.7, 95\% Cl 1.2-93.9) and to use the clinic, rather than an emergency room, as a primary source of medical care (OR 3.4, 95\% Cl 1.1-10.4).

Conclusions: Older IDUs with chronic wounds have different, and perhaps less risky, injection and hygiene behaviors than their peers and younger IDUs without wounds in Baltimore City. Because of these differences, older IDUs with wounds may be more receptive to community-based healthcare and substance abuse treatment messages.
\end{abstract}

Keywords: Chronic wounds, Injection drug use, Aging, Harm reduction

\section{Background}

Older injection drug users (IDUs) are a growing subgroup of active IDUs and IDUs seeking treatment [1-5]. It is estimated that the number of adults 50 years or older with substance use problems will double from an annual average of 2.8 million (2002-06) to 5.7 million by 2020 [6]. Age-associated health complications and ongoing chronic drug use may further intensify the social marginalization of older IDUs, which may diminish quality of life, access to health care and social productivity $[7,8]$. Furthermore, injection drug use has been associated

\footnotetext{
*Correspondence: kej1229@gmail.com

${ }^{1}$ Division of Infectious Diseases, Department of Medicine, Johns Hopkins Medical Institutions, 5200 Eastern Avenue, MFL Building, Center Tower, 3rd Floor, Baltimore, MD 21224, USA

Full list of author information is available at the end of the article
}

with accelerated biologic aging $[9,10]$ and the premature onset of health conditions normally associated with aging $[3,11,12]$. Due to these life course differences and evidence that IDUs have higher overall mortality rates, older IDUs are of growing interest to public health researchers and are typically defined as individuals older than $40-50$ years $[13,14]$.

Overall, older IDUs report impaired mental and physical health and functioning compared to age- and gendermatched population standards $[15,16]$. Older IDUs often self-reported health conditions such as deep vein thrombosis, skin ulcers, respiratory problems, diabetes, hypertension, hepatitis, and liver cirrhosis $[8,15]$. Studies on venous damage and chronic venous insufficiency (CVI) in 
IDUs revealed that CVI develops prematurely in IDUs $[11,12]$.

Certain risky injection drug use behaviors such as sharing needles, subcutaneous injection (skin-popping), injecting a mixture of heroin and cocaine (speedballing), using cigarette filters to draw up prepared drug, and injection under unhygienic conditions, have been linked to adverse outcomes such as abscesses, skin and soft tissue infections, injection site ulcers, and endocarditis [17-25]. Local and national public health authorities have implemented harm reduction measures to raise awareness and to educate IDUs regarding these risky behaviors. However, efforts have not been focused on raising awareness of the long-term consequences of injectionrelated venous damage among IDUs, which can lead to CVI and lower extremity ulcers. The effectiveness of these programs may also be attenuated by an individual's severity of addiction, socio-cultural environment and prior exposure to harm reduction messages [5].

Some studies have determined that older IDUs who started injecting at a young age, as opposed to later in adulthood, were more likely to have high-risk injection practices including sharing of injection equipment and more frequent injection [26,27]. In addition, the existing literature regarding the aging IDU population focuses on general physical and mental health conditions or injection-related behaviors [13,15,16,26-29]. The injection behaviors and socio-demographic characteristics of IDUs living with chronic wounds have not been well explored, even though chronic wounds are a significant health concern among older active or former IDUs.

We examined the prevalence of chronic wounds and associated injection-related behaviors among an IDU population accessing needle exchange services from the Baltimore City mobile Needle Exchange Program (BNEP), which has been in operation since 1994 [30]. We were interested specifically in determining whether there were distinctions between the demographics and behaviors of older IDUs living with chronic wounds as compared to their peers and younger IDUs. An improved understanding of the behaviors of older IDUs may help inform prevention strategies and both skin- and drugrelated treatment efforts for individuals living with chronic wounds.

\section{Methods}

We conducted a cross-sectional study among active IDU participants of the BNEP, age $\geq 18$ years, regardless of wound status. Data collection occurred between May 2012 and November 2013 and was conducted at five different exchange sites, though most participants were from Site A and Site B, which were 1.9 miles apart and demographically distinct. Site A is frequented primarily by African Americans and Site B is frequented primarily by Caucasians. Site $C$ was near several local exotic dance clubs and was geographically separate from Sites A and B.

All participants provided written, informed consent and completed a paper-administered survey including questions addressing demographics, injection behaviors, pre-injection skin care, wound history, wound care, and general medical history. Surveys required approximately 20 minutes and upon completion, participants were given a $\$ 10$ gift card for local businesses. Chronic wounds were defined as open areas on the skin that had been present and non-healing for $\geq 8$ weeks. Study team members visually verified the presence of chronic wounds at the time of the survey. This study was approved by the Johns Hopkins Medicine Institutional Review Board.

Participants were stratified into four groups by reported age ( $<45$ years or $\geq 45$ years) and wound status (presenting with a current chronic wound or without a current chronic wound). The primary outcome was considered the presence of a chronic wound among participants $\geq 45$ years. This outcome was independently compared to three distinct reference groups: 1) participants $<45$ years without chronic wounds; 2) participants $\geq 45$ years without chronic wounds; 3) participants $<45$ years with chronic wounds.

All variables were categorical except for age and number of times a needle was used, which were continuous variables. Predictor variables associated with the primary outcome group were analyzed using univariate and multivariate logistic regression. Odds ratios predicting risk of outcomes of interest with $95 \%$ confidence intervals were assessed. T-tests were used to compare means and/or proportions. $P$ values $\leq 0.05$ were considered statistically significant. Statistical analysis was performed using Stata 12 (StataCorp, College Station, TX).

\section{Results}

A total of 152 individuals were surveyed. The overall prevalence of chronic wounds was $19.7 \%(\mathrm{n} / \mathrm{N}=30 / 152)$. Of the 152 individuals, 73 were younger than 45 years (48.0\%) and 79 were aged 45 years or older (52.0\%). Of those with chronic wounds, 12 were in individuals younger than 45 years $(40.0 \%)$ and 18 were in individual aged 45 years or older $(60.0 \%)(p=0.121)$. We focused our analysis on the latter subgroup of participants: IDUs who were 45 years of age or older with at least one current chronic wound. This group accounted for $11.8 \%$ of all study participants (18/152).

Within the particular subgroup of interest (IDUs age $\geq 45$ years with chronic wound(s)), the median age was 55 years with an interquartile range (IQR) of 46-58. The participants were primarily male (61.1\%), African American (72.2\%), reported having stable housing (94.4\%), and had a self-reported HIV prevalence rate of $27.8 \%$ $(5 / 18)$. They reported long histories with injection drug use, most having injected for greater than 15 years 
Table 1 Socio-demographic, medical and injection behaviors by age and chronic wound status $\dagger$

\begin{tabular}{|c|c|c|c|c|c|c|c|c|}
\hline \multirow{3}{*}{ Description } & \multirow{3}{*}{$\begin{array}{l}\text { All participants } \\
\begin{array}{l}\text { No. }(\%) \\
N=152\end{array}\end{array}$} & \multirow{3}{*}{$\begin{array}{l}\text { Outcome group } \geq 45 \text { years, } \\
\text { with chronic wound } \\
\qquad \begin{array}{c}\text { No. (\%) } \\
N=18\end{array}\end{array}$} & \multicolumn{2}{|c|}{$\begin{array}{c}\text { Reference group } \\
\# 1<45 \text { years, no } \\
\text { chronic wound }\end{array}$} & \multicolumn{2}{|c|}{$\begin{array}{l}\text { Reference group } \\
\# 2 \geq 45 \text { years, no } \\
\text { chronic wound }\end{array}$} & \multicolumn{2}{|c|}{$\begin{array}{c}\text { Reference group } \\
\# 3<45 \text { years, with } \\
\text { chronic wound }\end{array}$} \\
\hline & & & No. (\%) & $p^{\mathrm{a}}$ & No. (\%) & & No. (\%) & $p^{\mathrm{a}}$ \\
\hline & & & $N=61$ & & $N=61$ & & $\mathrm{~N}=12$ & \\
\hline All participants $(\mathrm{N}=152)$ & $152(100.0)$ & $18(11.8)$ & $61(40.1)$ & $\ldots$ & $61(40.1)$ & $\ldots$ & $12(7.9)$ & $\ldots$ \\
\hline $\mathrm{Age}^{\mathrm{b}, \mathrm{c}}$ & $45 ;(35-52)$ & $55 ;(46-58)$ & $33 ;(28-39)$ & $<0.001^{*}$ & $52 ;(49-57)$ & 0.579 & $40 ;(35-42)$ & $<0.001^{*}$ \\
\hline \multicolumn{9}{|l|}{ Gender } \\
\hline Male & $96(63.2)$ & $11(61.1)$ & $31(50.8)$ & 0.442 & $48(78.7)$ & 0.131 & $6(50.0)$ & 0.548 \\
\hline Female & $56(36.8)$ & $7(38.9)$ & $30(49.2)$ & 0.442 & $13(21.3)$ & 0.131 & $6(50.0)$ & 0.548 \\
\hline \multicolumn{9}{|l|}{ Race } \\
\hline Caucasian & $75(49.3)$ & $4(22.2)$ & $47(77.1)$ & $<0.001^{*}$ & $16(26.2)$ & 0.701 & $8(66.7)$ & $0.015^{*}$ \\
\hline African American & $68(44.7)$ & $13(72.2)$ & $9(14.8)$ & $<0.001^{*}$ & $44(72.1)$ & 0.926 & $2(16.7)$ & $0.003^{*}$ \\
\hline Native American & $4(2.6)$ & $1(5.6)$ & $1(1.6)$ & 0.379 & $0(0.0)$ & 0.063 & $2(16.7)$ & 0.322 \\
\hline Other or Multiple ${ }^{d}$ & $5(3.3)$ & $0(0.0)$ & $4(6.6)$ & 0.263 & $1(1.6)$ & 0.589 & $0(0.0)$ & $\ldots$ \\
\hline \multicolumn{9}{|l|}{ Housing ${ }^{e}$} \\
\hline Stable & $113(74.3)$ & $17(94.4)$ & $41(67.2)$ & $0.022^{*}$ & $47(77.1)$ & 0.100 & $8(66.7)$ & $0.046^{*}$ \\
\hline Unstable & $39(25.7)$ & $1(5.6)$ & $20(32.8)$ & $0.022^{*}$ & $14(23.0)$ & 0.100 & $4(33.3)$ & $0.046^{*}$ \\
\hline \multicolumn{9}{|l|}{ Exchange site } \\
\hline Site A & $54(35.5)$ & $9(50.0)$ & $10(16.4)$ & $0.003^{*}$ & $34(55.7)$ & 0.670 & $1(8.3)$ & $0.018^{*}$ \\
\hline Site B & $72(47.4)$ & $5(27.8)$ & $40(65.6)$ & $0.004^{*}$ & $18(29.5)$ & 0.889 & $9(75.0)$ & $0.011^{*}$ \\
\hline Site $C$ & $5(3.3)$ & $0(0.0)$ & $4(6.6)$ & 0.263 & $0(0.0)$ & - & $1(8.3)$ & 0.214 \\
\hline Other & $21(13.8)$ & $4(22.2)$ & $7(11.5)$ & 0.249 & $9(14.8)$ & 0.457 & $1(8.3)$ & 0.316 \\
\hline Jail/prison - past 6 months & $45(29.6)$ & $1(5.6)$ & $28(45.9)$ & $0.002^{*}$ & $12(19.7)$ & 0.157 & $4(33.3)$ & $0.046^{*}$ \\
\hline \multicolumn{9}{|l|}{ Years injecting drugs } \\
\hline$\leq 2$ & $15(9.9)$ & $0(0.0)$ & $12(19.7)$ & $0.041^{*}$ & $2(3.3)$ & 0.435 & $1(8.3)$ & 0.214 \\
\hline $3-8$ & $25(16.4)$ & $0(0.0)$ & $18(29.5)$ & $0.009^{*}$ & $5(8.2)$ & 0.209 & $2(16.7)$ & 0.073 \\
\hline $9-14$ & $20(13.2)$ & $1(5.6)$ & $12(19.7)$ & 0.157 & $5(8.2)$ & 0.715 & $2(16.7)$ & 0.322 \\
\hline$\geq 15$ & $92(60.5)$ & $17(94.4)$ & $19(31.2)$ & $<0.001^{*}$ & $49(80.3)$ & 0.157 & $7(58.3)$ & $0.016^{*}$ \\
\hline \multicolumn{9}{|l|}{ Injection site location } \\
\hline Arm & $92(60.5)$ & $7(38.9)$ & $38(62.3)$ & 0.078 & $39(63.9)$ & 0.059 & $8(66.7)$ & 0.136 \\
\hline Leg & $37(24.3)$ & $11(61.1)$ & $8(13.1)$ & $<0.001^{*}$ & $16(26.2)$ & $0.006^{*}$ & $2(16.7)$ & $0.016^{*}$ \\
\hline Neck & $17(11.2)$ & $4(22.2)$ & $10(16.4)$ & 0.571 & $2(3.3)$ & $0.008^{*}$ & $1(8.3)$ & 0.317 \\
\hline Drug treatment program ${ }^{f}$ & $36(23.7)$ & $8(53.3)$ & $12(20.7)$ & $0.012^{*}$ & $15(25.4)$ & $0.037^{*}$ & $1(11.1)$ & $0.039^{*}$ \\
\hline Using cigarette filter ${ }^{9}$ & $65(42.8)$ & $2(11.8)$ & $31(51.7)$ & $0.003^{*}$ & $28(46.7)$ & $0.009^{*}$ & $4(40.0)$ & 0.089 \\
\hline Using needles (\# of times) ${ }^{h}$ & $3 ; 1-4$ & $1 ; 1-3$ & $3 ; 2-7$ & $<0.001^{*}$ & $2 ; 1-3$ & $0.021^{*}$ & $3 ; 2-3$ & 0.112 \\
\hline \multicolumn{9}{|l|}{ Clean needles upon reuse ${ }^{i}$} \\
\hline Water & $56(50.5)$ & $1(12.5)$ & $29(60.4)$ & $0.012^{*}$ & $23(51.1)$ & $0.043^{*}$ & $3(30.0)$ & 0.375 \\
\hline Bleach & $55(49.5)$ & $7(87.5)$ & 19 (39.6) & $0.012^{*}$ & $22(48.9)$ & $0.043^{*}$ & $7(70.0)$ & 0.375 \\
\hline \multicolumn{9}{|l|}{ Cleaning injection site } \\
\hline Do not clean & $35(23.0)$ & $4(22.2)$ & $13(21.3)$ & 0.935 & $12(19.7)$ & 0.817 & $6(50.0)$ & 0.114 \\
\hline Water & $12(7.9)$ & $0(0.0)$ & $4(6.6)$ & 0.263 & $7(11.5)$ & 0.132 & $1(8.3)$ & 0.214 \\
\hline Soap/water & $14(9.2)$ & $0(0.0)$ & $9(14.8)$ & 0.083 & $4(6.6)$ & 0.263 & $1(8.3)$ & 0.214 \\
\hline Alcohol & $83(54.6)$ & $13(72.2)$ & $33(54.1)$ & 0.171 & $34(55.7)$ & 0.210 & $3(25.0)$ & $0.011^{*}$ \\
\hline Multiple or other & $8(5.3)$ & $1(5.6)$ & $2(3.3)$ & 0.655 & $4(6.6)$ & 0.879 & $1(8.3)$ & 0.772 \\
\hline
\end{tabular}


Table 1 Socio-demographic, medical and injection behaviors by age and chronic wound status † (Continued)

\begin{tabular}{|c|c|c|c|c|c|c|c|c|}
\hline \multicolumn{9}{|l|}{ Medical care provider } \\
\hline Clinic & $48(31.6)$ & $9(50.0)$ & $14(23.0)$ & $0.027^{*}$ & $23(37.7)$ & 0.350 & $2(16.7)$ & 0.064 \\
\hline Private doctor & $14(9.2)$ & $1(5.6)$ & $5(8.2)$ & 0.715 & $6(9.8)$ & 0.581 & $2(16.7)$ & 0.322 \\
\hline Emergency room & $85(55.9)$ & $8(44.4)$ & $42(68.9)$ & 0.058 & $28(45.9)$ & 0.911 & $7(58.3)$ & 0.456 \\
\hline Other & $5(3.3)$ & $0(0.0)$ & $0(0.0)$ & - & $4(6.6)$ & 0.263 & $1(8.3)$ & 0.214 \\
\hline
\end{tabular}

† All numbers have been rounded to nearest decimal place.

${ }^{a} p$ values refer to the comparison between the Reference group and the Outcome Group. $p$ value for "Age" was obtained using two-group mean comparison t-test. All other $p$ values were obtained using two-group proportion t-test.

${ }^{\mathrm{b}}$ Continuous variable.

'Median; (Interquartile range).

${ }^{\mathrm{d}}$ Hispanic, Asian, multiple.

eUnstable includes living in a shelter, on the streets, in an abandoned unit, no set place, or multiple. Stable housing includes living in an owned/rented house, subsidized housing, with a friend, other (e.g. transitional house).

fParticipant in a drug treatment program; Denominator changes where responses were missing: All: $N=152 ;$ Outcome group: $N=15 ;$ Reference group \#1: $N=58$; Reference group \#2: 59; Reference group \#3: $\mathrm{N}=9$.

IUsing cigarette filters to draw up prepared drug; Denominator changes where responses were missing: All: $N=152 ;$ Outcome group: $N=17$; Reference group \#1: $\mathrm{N}=60$; Reference group \#2: 60; Reference group \#3: $\mathrm{N}=10$.

hDenominator changes where responses were missing: All: $N=150$; Outcome group: $N=17$; Reference group \#1: $N=61$; Reference group \#2: 60 ; Reference group $\# 3: \mathrm{N}=12$.

'Includes only participants who reported reusing needles. All: $\mathrm{N}=111$; Outcome group: $\mathrm{N}=8$; Reference group \#1: $\mathrm{N}=48$; Reference group \#2: 45; Reference group $\# 3: \mathrm{N}=10$.

${ }^{\mathrm{j}}$ Most frequent method of cleaning injection site before injection; "Other" includes bleach, saliva, baby wipe, multiple agents. ${ }^{*} p \leq 0.05$.

(94.4\%). The most frequently reported injection behaviors included daily heroin injection (72.2\%), daily speedball injection (55.6\%), leg injection (61.1\%) and cleaning the injection site with alcohol before injecting (72.2\%). Of the nine participants who reported reusing their needles $(9 / 18,50.0 \%)$, seven of eight reported cleaning their needles with bleach prior to reuse (87.5\%). Older IDUs with chronic wounds also reused their needles less frequently compared to their peers without wounds $(p=0.021)$ and compared to younger IDUs without wounds $(p<0.001)$. See Table 1 for additional information on demographics, injection practices and medical history for all participants, participants in the outcome group (IDUs age $\geq 45$ years with chronic wound(s)), and participants in the three reference groups.

\section{Older IDUs with chronic wounds compared to younger IDUs without wounds}

Compared to individuals younger than 45 years who did not have chronic wounds, the univariate analysis indicated that participants older than 45 years old with chronic wounds were more likely to be African American compared to Caucasian (Odds ratio (OR) 17.0, 95\% Confidence interval (CI) $4.5-64.1, p<0.001)$, to have stable housing (OR 8.3, 95\% CI 1.0-66.8, $p=0.047$ ), to visit a clinic as their primary source of medical care rather than an emergency room (OR 3.4, 95\% CI 1.1-10.4, $p=0.035$ ), and to frequent BNEP site A versus Site B (OR 7.2, 2.0-26.3, $p=0.003$ ) (Table 2A). They were also more likely to have injected drugs for 15 or more years (OR 10.7, 95\% CI 1.3-91.5, $p=0.030$ ), to be participating in a drug treatment program (OR 4.4, 95\% CI 1.3-14.5, $p=0.016$ ), to inject speedball everyday (OR 4.2, 95\% CI 1.1-15.7, $p=0.035$ ), to inject into the leg (OR 10.4, 95\% CI 3.1-34.7, $p=<0.001)$ and to clean needles with bleach upon reuse (OR 10.7, 95\% CI $1.2-93.9, p=0.033$ ). Additionally, they were less likely to have been in jail or prison for more than 24 hours during the past 6 months (OR 0.07, 95\% CI 0.009-0.6, $p=0.012$ ), and also less likely to use cigarette filters to draw up prepared drug (OR 0.1, 95\% CI 0.03-0.6, $p=0.009$ ).

In the multivariate model, older individuals with wounds were more likely to be African American (Adjusted odds ratio (AOR) 16.3, 95\% CI 1.4-190.3, $p=0.026$ ) and inject into the leg (AOR 9.9, 95\% CI 1.3-73.1, $p=0.024$ ), and they were less likely to use cigarette filters (AOR $0.06,95 \% \mathrm{CI}$ $0.004-0.9, p=0.039$ ) (Table 2B).

\section{Older IDUs with chronic wounds compared to similar-aged peers without wounds}

Among participants 45 years or older, those with a chronic wound were more likely to be in a drug treatment program (OR 3.4, 95\% CI 1.0-10.8, $p=0.043$ ), and to inject into the leg (OR 4.4, 95\% CI 1.5-13.4, $p=0.008$ ) or neck (OR 8.4, 95\% CI 1.4-50.7, $p=0.020$ ), compared to the same age group without chronic wounds (Table $3 \mathrm{~A}$ ). In the multivariable model, older individuals with chronic wounds remained less likely to use cigarette filters when drawing up prepared drug into the syringe (AOR 0.1, 95\% CI $0.01-0.9, p=0.044$ ) (Table 3B).

\section{Older IDUs with chronic wounds compared to younger IDUs with wounds}

Among participants with chronic wounds, those 45 years or older were more likely to be African American (OR 13.0, 95\% CI 1.9-88.0, $p=0.009$ ), to exchange needles at Site A compared to Site B (OR 16.2, 95\% CI 1.6-167.7, 
Table 2 Group \#1: Older IDUs with chronic wounds compared to younger IDUs without wounds

\begin{tabular}{|c|c|c|c|c|c|c|}
\hline & \multicolumn{3}{|c|}{ A. univariate $(\mathrm{N}=79)$} & \multicolumn{3}{|c|}{ B. multivariate ${ }^{a}(\mathrm{~N}=71)$} \\
\hline & OR & $95 \% \mathrm{Cl}$ & $p$ & OR & $95 \% \mathrm{Cl}$ & $p$ \\
\hline \multicolumn{7}{|l|}{ Race } \\
\hline Caucasian & Ref & & & Ref & & \\
\hline African American & 17.0 & $4.5-64.1$ & $<0.001^{*}$ & 16.3 & $1.4-190.3$ & $0.026^{*}$ \\
\hline Native American & 11.8 & $0.6-225.4$ & 0.102 & 9.3 & $0.2-475.3$ & 0.268 \\
\hline Other & $\ldots{ }^{b}$ & & & & & \\
\hline \multicolumn{7}{|l|}{ Housing $^{c}$} \\
\hline Unstable & Ref & & & & & \\
\hline Stable & 8.3 & $1.0-66.8$ & $0.047^{*}$ & $\ldots^{d}$ & & \\
\hline \multicolumn{7}{|l|}{ Medical Care } \\
\hline Emergency room & Ref & & & & & \\
\hline Clinic & 3.4 & $1.1-10.4$ & $0.035^{*}$ & ${ }^{d}$ & & \\
\hline Private doctor & 1.1 & $0.1-10.2$ & 0.996 & & & \\
\hline Other &.$^{\mathrm{b}}$ & & & & & \\
\hline \multicolumn{7}{|l|}{ Exchange site $(N=29)$} \\
\hline Site A & Ref & & & Ref & & \\
\hline Site B & 7.2 & $2.0-26.3$ & $0.003^{*}$ & 1.5 & $0.2-12.0$ & 0.719 \\
\hline Site C & 4.6 & $1.0-21.3$ & $0.053^{*}$ & 17.8 & $1.2-254.5$ & $0.034^{*}$ \\
\hline \multicolumn{7}{|c|}{ Time injecting drugs (years) } \\
\hline $9-14$ & Ref & & & & & \\
\hline$\geq 15$ & 10.7 & $1.3-91.5$ & $0.030^{*}$ & $\ldots{ }^{d}$ & & \\
\hline \multicolumn{7}{|c|}{ Participating in drug treatment program } \\
\hline No & Ref & & & & & \\
\hline Yes & 4.4 & $1.3-14.5$ & $0.016^{*}$ & $\ldots^{d}$ & & \\
\hline \multicolumn{7}{|l|}{ Speedball } \\
\hline Never & Ref & & & & & \\
\hline Occasionally & 1.2 & $0.3-5.3$ & 0.820 &.$^{d}$ & & \\
\hline Everyday & 4.2 & $1.1-15.7$ & $0.035^{*}$ & & & \\
\hline \multicolumn{7}{|l|}{ Injecting into leg } \\
\hline No & Ref & & & Ref & & \\
\hline Yes & 10.4 & $3.1-34.7$ & $<0.001^{*}$ & 9.9 & $1.3-73.1$ & $0.024^{*}$ \\
\hline \multicolumn{7}{|l|}{ Skin-popping } \\
\hline No & Ref & & & & & \\
\hline Yes & 4.4 & $1.0-19.9$ & 0.055 & $\ldots^{d}$ & & \\
\hline \multicolumn{7}{|c|}{ Cleaning needle with bleach upon reuse } \\
\hline Water & Ref & & & & & \\
\hline Bleach & 10.7 & $1.2-93.9$ & $0.033^{*}$ &.$^{d}$ & & \\
\hline \multicolumn{7}{|c|}{ Jail/Prison during last 6 months } \\
\hline No & Ref & & & & & \\
\hline Yes & 0.07 & $0.009-0.6$ & $0.012^{*}$ & $\ldots{ }^{d}$ & & \\
\hline
\end{tabular}


Table 2 Group \#1: Older IDUs with chronic wounds compared to younger IDUs without wounds (Continued)

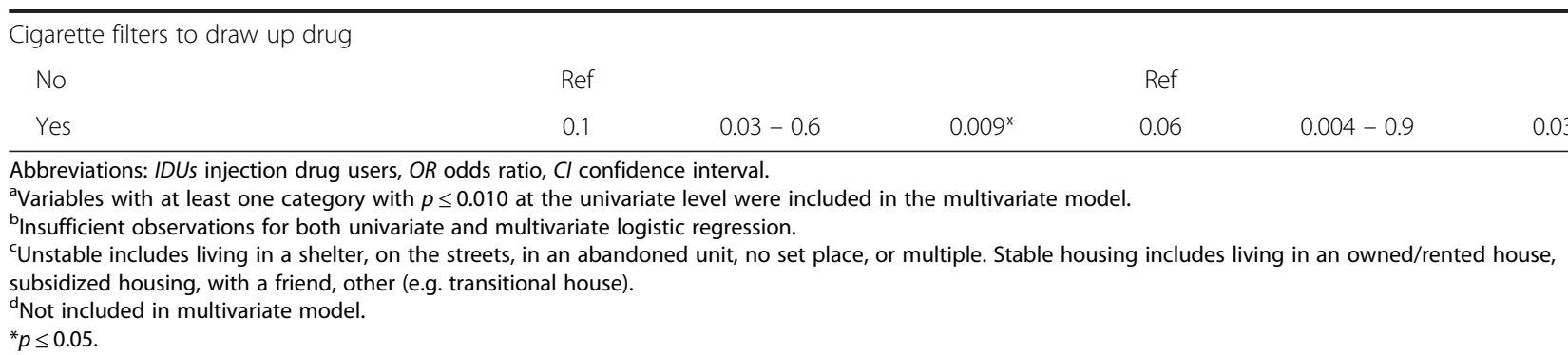

$p=0.020)$, to inject into the leg (OR 7.9, 95\% CI 1.3-47.0, $p=0.024)$, and to clean the injection site with alcohol before injection (OR 6.5, 95\% CI 1.1-38.6, $p=0.040$ ) when compared to younger IDUs with chronic wounds (Table 4A). In the multivariate model, leg injection was more common among older individuals with chronic wounds (AOR 31.3, 95\% CI 1.1-873.6, $p=0.043$ ) (Table 4B).

\section{Discussion}

The high prevalence of chronic wounds in our communityrecruited IDU study population (19.7\%) and the disproportionate overrepresentation of older IDUs with chronic wounds (60\%) suggests the need for focused interventions to improve awareness of injection-related venous damage and chronic wounds in IDUs to better prevent and treat this condition.

Upon comparing older IDUs with chronic wounds to their same-aged peers without chronic wounds and to younger IDUs with and without wounds, this group of older individuals with wounds appeared to engage in behaviors that were more consistent with self-care habits and less-risky injection practices. For example, they were more likely to have stable housing, use a clinic rather than an emergency room as the primary source of medical care, participate in a drug treatment program, clean needles with bleach, and clean their injection site with alcohol before injection. They were also less likely to have been recently in jail or prison, or to have used cigarette filters to draw up prepared drug. Use of cigarette filters, rather than needle exchange-distributed packed cotton filters, is considered riskier behavior and generally discouraged by harm reduction advocates because it is less effective at filtering particles out of the drug and can be associated with endocarditis or phlebitis [23,31]. It is possible that older IDUs with wounds are in a different stage of life, as they have survived for many years with substance abuse issues and have perhaps learned to cope with their substance abuse and chronic health conditions better

Table 3 Group \#2: Older IDUs with chronic wounds compared to older IDUs without wounds

\begin{tabular}{|c|c|c|c|c|c|c|}
\hline & \multicolumn{3}{|c|}{ A. univariate $(\mathrm{N}=79)$} & \multicolumn{3}{|c|}{ B. multivariate ${ }^{a}(N=72)$} \\
\hline & $\overline{\mathrm{OR}}$ & $95 \% \mathrm{Cl}$ & $p$ & OR & $95 \% \mathrm{Cl}$ & $p$ \\
\hline \multicolumn{7}{|c|}{ Trading sex for money } \\
\hline No & Ref & & & Ref & & \\
\hline Yes & 3.3 & $1.1-10.0$ & $0.039^{*}$ & 2.3 & $0.4-13.9$ & 0.346 \\
\hline \multicolumn{7}{|c|}{ Participating in drug treatment program } \\
\hline No & Ref & & & Ref & & \\
\hline Yes & 3.4 & $1.0-10.8$ & $0.043^{*}$ & 3.2 & $0.8-12.9$ & 0.098 \\
\hline \multicolumn{7}{|c|}{ Injecting into leg } \\
\hline No & Ref & & & Ref & & \\
\hline Yes & 4.4 & $1.5-13.4$ & $0.008^{*}$ & 3.2 & $0.7-13.4$ & 0.120 \\
\hline \multicolumn{7}{|c|}{ Injecting into neck } \\
\hline No & Ref & & & Ref & & \\
\hline Yes & 8.4 & $1.4-50.7$ & $0.020^{*}$ & 4.9 & $0.4-58.3$ & 0.212 \\
\hline \multicolumn{7}{|c|}{ Using cigarette filters to draw up drug } \\
\hline No & Ref & & & Ref & & \\
\hline Yes & 0.2 & $0.03-0.7$ & $0.018^{*}$ & 0.1 & $0.01-0.9$ & $0.044^{*}$ \\
\hline
\end{tabular}

Abbreviations: IDUs injection drug users, OR odds ratio, $\mathrm{Cl}$ confidence interval.

${ }^{a}$ Variables with at least one category with $p \leq 0.050$ at the univariate level were included in the multivariate model.

${ }^{*} p \leq 0.05$. 
Table 4 Group \#3: Older IDUs with chronic wounds compared to younger IDUs with wounds

\begin{tabular}{|c|c|c|c|c|c|c|}
\hline & \multicolumn{3}{|c|}{ A. univariate $(\mathrm{N}=30)$} & \multicolumn{3}{|c|}{ B. multivariate ${ }^{a}(\mathrm{~N}=21)$} \\
\hline & OR & $95 \% \mathrm{Cl}$ & $p$ & OR & $95 \% \mathrm{Cl}$ & $p$ \\
\hline \multicolumn{7}{|l|}{ Race } \\
\hline Caucasian & Ref & & & Ref & & \\
\hline African American & 13.0 & $1.9-88.0$ & $0.009^{*}$ & 4.3 & $0.06-290.1$ & 0.502 \\
\hline Native American & 1.0 & $0.07-14.6$ & 1.000 & 0.1 & $0.001-12.7$ & 0.387 \\
\hline Other & $\ldots^{b}$ & & & & & \\
\hline \multicolumn{7}{|l|}{ Exchange site $(N=29)$} \\
\hline Site A & Ref & & & Ref & & \\
\hline Site B & 16.2 & $1.6-167.7$ & $0.020^{*}$ & 2.0 & $0.03-146.2$ & 0.751 \\
\hline Site $C$ & 7.2 & $0.6-83.3$ & 0.114 & ${ }^{b}$ & & \\
\hline \multicolumn{7}{|l|}{ Injecting into leg } \\
\hline No & Ref & & & Ref & & \\
\hline Yes & 7.9 & $1.3-47.0$ & $0.024^{*}$ & 31.3 & $1.1-873.6$ & $0.043^{*}$ \\
\hline \multicolumn{7}{|c|}{ Cleaning injection site before injection $(N=26)^{c}$} \\
\hline Do not clean & Ref & & & Ref & & \\
\hline Alcohol & 6.5 & $1.1-38.6$ & $0.040^{*}$ & 13.5 & $0.5-390.6$ & 0.130 \\
\hline $\begin{array}{l}\text { Abbreviations: OR odds } \\
\text { a Variables with at least } \\
\text { b Insufficient observatio } \\
\text { 'Other categories with } \\
\text { soap/water, multiple o } \\
{ }^{\circ} p \leq 0.05 \text {. }\end{array}$ & iriate & $\begin{array}{l}\text { included in } \\
\text { iate analysis }\end{array}$ & $\begin{array}{l}\text { ivariate } \\
\text { sufficien }\end{array}$ & tions. & variables inclu & \\
\hline
\end{tabular}

than younger IDUs. It remains to be determined if these differences in behaviors surrounding injection and cleanliness are a result of living with a chronic wound, maturing as an injection drug user and/or the internalization of the syringe exchange program's ongoing harm reduction messages and education.

Older IDUs with wounds were more likely to be African American even after adjusting for exchange site. In contrast, younger IDUs were more likely to be Caucasian. These findings may be a reflection of the drug use patterns in Baltimore City and at the BNEP sites that were surveyed. This suggests that there are racial and/ or socio-cultural differences among younger Caucasian IDUs that may lend preference for certain, and perhaps riskier, injection-related and other destabilizing behaviors that may lead to increased rates of homelessness and incarceration, among other factors, that we observed in this analysis. Understanding these differences within local subgroups of an IDU population may facilitate more targeted harm reduction efforts.

Other findings from this study are consistent with a population engaged in long-term injection drug use, which can lead to venous scarring and venous disease. As IDUs mature in their injection drug use habits, there may be increasing reliance on injecting into veins in other locations such as the leg or neck, as we observed among the older IDUs with wounds. Chronic wounds appear to be associated with prolonged drug use, even among the younger IDUs, as the majority of younger IDUs with chronic wounds had also been injecting for at least 15 years. Injecting into the leg together with prolonged injection drug use, resultant venous damage and physiologic aging of the veins, likely puts older IDUs at heightened risk for both CVI and lower extremity ulcers [32].

Our study had limitations. Participants were active members of the BNEP, and therefore they may report different injection and skin care practices than IDUs not accessing community-based harm reduction services and education. The survey also relied upon self-reported data. Additionally, there were limitations associated with the small sample size of individuals with chronic wounds, however the overall cohort size and survey design was sufficient to characterize some behaviors as truly distinct in the population with chronic wounds. Despite these potential limitations, we report for the first time self-care behaviors among older IDUs living with chronic wounds in a mobile metropolitan needle exchange program in Baltimore City.

\section{Conclusions}

Our findings suggest that older IDUs with chronic wounds have different, and perhaps less risky, injection and hygiene practices than their peers and younger IDUs without wounds. Moreover, older IDUs with chronic wounds may represent a different demographic among those using illicit substances and a distinct IDU subgroup that may be more receptive to local healthcare and/or substance abuse 
treatment messages. This subgroup may also be more likely to engage in meaningful relationships and therapeutic alliances with medical providers to address drug use and/or health conditions previously neglected.

Future public health and harm reduction interventions to raise awareness of the known associations between injection practices, venous damage, and chronic wounds among IDUs who have recently initiated injecting and among IDUs who have a prolonged injection history may represent valuable measures to prevent long-term wound-associated morbidity and disability. Harm reduction programs should consider including such educational information and referrals to local wound care centers in their regular encounters with IDUs.

\section{Abbreviations \\ IDUs: Injection drug users; CVI: Chronic venous insufficiency; IQR: Interquartile range; OR: Odds ratio; Cl: Confidence interval; AOR: Adjusted odds ratio.}

\section{Competing interests}

The authors declare that they have no competing interests.

\section{Authors' contributions}

KEJ conceived the study. KEJ and NR participated in the design of the study. MES, NR and KEJ participated in data collection. MES performed statistical analysis and drafted the manuscript under the guidance of KEJ. NR provided valuable feedback on manuscript drafts. PC assisted in study design and implementation. All authors read and approved the final manuscript.

\section{Authors' information}

MES has a Bachelor of Science in Molecular and Cellular Biology and a Bachelor of Arts in History of Science, Technology and Medicine from the Johns Hopkins University. She is currently a research assistant for KEJ at the Johns Hopkins Medical Institutions.

NR obtained her Master of Science in Public Health from the Johns Hopkins Bloomberg School of Public Health. She has extensive experience with harm reduction efforts and works for the Baltimore City Health Department's Community Risk Reduction Services.

$\mathrm{PC}, \mathrm{MD}, \mathrm{MPH}$, is the Acting Deputy Commissioner, Division of Disease Control, Baltimore City Department of Health and has extensive experience in congressional, state, and municipal health and public health public policy. KEJ, MD, MSc is Assistant Professor of Medicine in the Division of Infectious Diseases at the Johns Hopkins University School of Medicine. She completed a residency in Internal Medicine at the University of Colorado and a fellowship in Infectious Diseases at Johns Hopkins University. She has significant experience in translational research and public health program implementation. She is the primary physician for the BNEP's wound care clinic and for this research study.

\section{Acknowledgements}

The authors would like to acknowledge the Baltimore City Health Department Office of Community Risk Reduction Services, the Needle Exchange Program staff, clients, and study participants, the Johns Hopkins Bayview Medical Center Division of Infectious Diseases, and the Johns Hopkins Wound Healing Center. This work was supported by The Johns Hopkins University Woodrow Wilson Undergraduate Research Fellowship Program (MES); The Johns Hopkins University Center for AIDS Research, Baltimore HIV/AIDS Scholars Program 1P30A1094189 (MES); and The National Institutes of Health K23AI083100 (KEJ). The funding organizations had no role in the study design, data collection, data analysis, interpretation of data or writing and submission of the manuscript.

\section{Author details}

${ }^{1}$ Division of Infectious Diseases, Department of Medicine, Johns Hopkins Medical Institutions, 5200 Eastern Avenue, MFL Building, Center Tower, 3rd Floor, Baltimore, MD 21224, USA. ${ }^{2}$ Baltimore City Health Department, 1001 E. Fayette Street, Baltimore, MD 21202, USA.
Received: 4 June 2014 Accepted: 22 September 2014

Published: 19 October 2014

\section{References}

1. Armstrong GL: Injection drug users in the United States, 1979-2002: an aging population. Arch Intern Med 2007, 167(2):166.

2. Beynon CM, McVeigh J, Roe B: Problematic drug use, ageing and older people: trends in the age of drug users in northwest England. Ageing Soc 2007, 27(6):799-810.

3. Beynon CM: Drug use and ageing: older people do take drugs! Age Ageing 2009, 38(1):8-10.

4. Boddiger D: Drug abuse in older US adults worries experts. Lancet 2008, 372(9650):1622.

5. Boeri MW: "Hell, I'm an addict, but I ain't No junkie": an ethnographic analysis of aging heroin users. Hum Organ 2004, 63(2):236-245.

6. Han B, Gfroerer JC, Colliver JD, Penne MA: Substance use disorder among older adults in the United States in 2020. Addiction 2009, 104(1):88-96.

7. Anderson TL, Levy JA: Marginality among older injectors in today's illicit drug culture: assessing the impact of ageing. Addiction 2003, 98(6):761-770.

8. Roe B, Beynon C, Pickering L, Duffy P: Experiences of drug use and ageing: health, quality of life, relationship and service implications. J Adv Nurs 2010, 66(9):1968-1979.

9. Cheng G, Zeng H, Leung M, Zhang H, Lau B, Liu Y, Liu G, Sham P, Chan C, So K: Heroin abuse accelerates biological aging: a novel insight from telomerase and brain imaging interaction. Trans/ Psychiatry 2013, 3(5):e260.

10. Reece AS: Evidence of accelerated ageing in clinical drug addiction from immune, hepatic and metabolic biomarkers. Immun Ageing 2007, 4(6) doi:10.1186/1742-4933-4-6.

11. Pieper $B$, Templin T: Chronic venous insufficiency in persons with a history of injection drug use. Res Nurs Health 2001, 24(5):423-432.

12. Pieper B, Kirsner RS, Templin TN, Birk TJ: Injection drug use: an understudied cause of venous disease. Arch Dermatol 2007, 143(10):1305-1309.

13. Rosen D, Hunsaker A, Albert SM, Cornelius JR, Reynolds CF III: Characteristics and consequences of heroin use among older adults in the United States: a review of the literature, treatment implications, and recommendations for further research. Addict Behav 2011, 36(4):279-285.

14. Smyth B, Hoffman V, Fan J, Hser Y: Years of potential life lost among heroin addicts 33 years after treatment. Prev Med 2007, 44(4):369-374.

15. Grella CE, Lovinger K: Gender differences in physical and mental health outcomes among an aging cohort of individuals with a history of heroin dependence. Addict Behav 2012, 37(3):306-312.

16. Hser Y, Gelberg L, Hoffman V, Grella CE, McCarthy W, Anglin MD: Health conditions among aging narcotics addicts: medical examination results. J Behav Med 2004, 27(6):607-622

17. Binswanger IA, Kral AH, Bluthenthal RN, Rybold DJ, Edlin BR: High prevalence of abscesses and cellulitis among community-recruited injection drug users in San Francisco. Clin Infect Dis 2000, 30(3):579-581.

18. Ebright JR, Pieper B: Skin and soft tissue infections in injection drug users. Infect Dis Clin North Am 2002, 16(3):697-712.

19. Fink DS, Lindsay SP, Slymen DJ, Kral AH, Bluthenthal RN: Abscess and self-treatment among injection drug users at four California syringe exchanges and their surrounding communities. Subst Use Misuse 2013, 48(7):523-531.

20. Hope V, Marongiu A, Parry J, Ncube F: The extent of injection site infection in injecting drug users: findings from a national surveillance study. Epidemiol Infect 2010, 138(10):1510-1518.

21. Murphy EL, DeVita D, Liu H, Vittinghoff E, Leung P, Ciccarone DH, Edlin BR: Risk factors for skin and soft-tissue abscesses among injection drug users: a case-control study. J Infect Dis 2001, 33:35-40.

22. Phillips KT, Stein MD: Risk practices associated with bacterial infections among injection drug users in Denver, Colorado. Am J Drug Alcohol Abuse 2010, 36(2):92-97.

23. Scott J: Laboratory study of the effectiveness of filters used by heroin injectors. J Subst Use 2005, 10(5):293-301.

24. Spijkerman IJ, van Ameijden EJ, Mientjes GH, Coutinho RA, van den Hoek A: Human immunodeficiency virus infection and other risk factors for skin abscesses and endocarditis among injection drug users. J Clin Epidemiol 1996, 49(10):1149-1154.

25. Vlahov D, Sullivan M, Astemborski J, Nelson KE: Bacterial infections and skin cleaning prior to injection among intravenous drug users. Public Health Rep 1992, 107(5):595. 
26. Boeri MW, Sterk CE, Elifson KW: Reconceptualizing early and late onset: a life course analysis of older heroin users. Gerontologist 2008, 48(5):637-645.

27. Lopez WD, Krueger PM, Walters ST: High-risk drug use and sexual behaviors among out-of-treatment drug users: An aging and life course perspective. Addict Behav 2010, 35(5):432-437.

28. Bourgois P, Martinez A, Kral A, Edlin BR, Schonberg J, Ciccarone D: Reinterpreting ethnic patterns among white and African American men who inject heroin: a social science of medicine approach. PLoS Med 2006, 3(10):1805-1815.

29. Rosen D, Smith ML, Reynolds CF III: The prevalence of mental and physical health disorders among older methadone patients. Am J Geriatr Psychiatry 2008, 16(6):488-497.

30. Gindi RM, Rucker MG, Serio-Chapman CE, Sherman SG: Utilization patterns and correlates of retention among clients of the needle exchange program in Baltimore, Maryland. Drug Alcohol Depend 2009, 103(3):93-98.

31. Ponton R, Scott J: Injection preparation processes used by heroin and crack cocaine injectors. J Subst Use 2004, 9(1):7-19.

32. Pieper B, Templin TN, Kirsner RS, Birk TJ: Impact of injection drug use on distribution and severity of chronic venous disorders. Wound Repair Regen 2009, 17(4):485-491.

doi:10.1186/1477-7517-11-28

Cite this article as: Smith et al: Self-care and risk reduction habits in older injection drug users with chronic wounds: a cross-sectional study. Harm Reduction Journal 2014 11:28.

\section{Submit your next manuscript to BioMed Central and take full advantage of:}

- Convenient online submission

- Thorough peer review

- No space constraints or color figure charges

- Immediate publication on acceptance

- Inclusion in PubMed, CAS, Scopus and Google Scholar

- Research which is freely available for redistribution 